\author{
CRADA Final Report \\ for \\ CRADA Number ORNL92-0143 \\ SURFACE TREATMENT FOR IMPROVING \\ SULFIDATION RESISTANCE OF FOSSIL \\ POWER SYSTEMS
}

V. K. Sikka and M. L. Santella

Oak Ridge National Laboratory

D. A. Canonico

ABB Combustion Engineering, Inc.

Date Published: January 2001

Prepared by the

Oak Ridge National Laboratory

Oak Ridge, Tennessee 37831

Managed by

UT-Battelle, LLC

For the

U.S. Department of Energy

Under contract DE-AC05-00OR22725

APPROVED FOR PUBLIC RELEASE

UNLIMITED DISTRIBUTION 
Metals and Ceramics

CRADA Final Report

For

CRADA Number ORNL92-0143

\title{
SURFACE TREATMENT FOR IMPROVING SULFIDATION RESISTANCE OF FOSSIL POWER SYSTEMS
}

\author{
V. K. Sikka and M. L. Santella \\ Oak Ridge National Laboratory \\ D. A. Canonico \\ ABB Combustion Engineering, Inc.
}

Date Published: January 2001

Prepared by the Oak Ridge National Laboratory

Oak Ridge, Tennessee 37831

Managed by

UT-Battelle, LLC

For the

U.S. Department of Energy

Under contract DE-AC05-00OR22725

APPROVED FOR PUBLIC RELEASE

UNLIMITED DISTRIBUTION 


\section{CONTENTS}

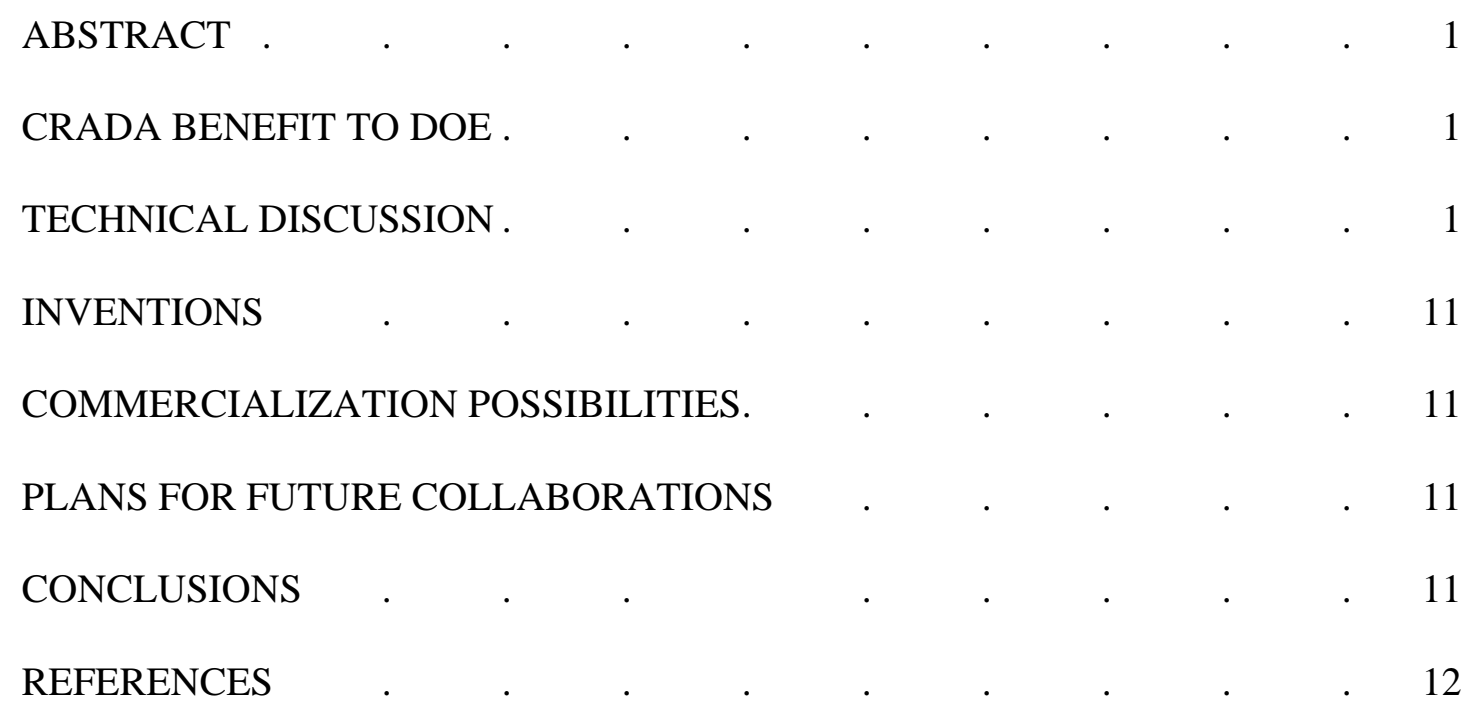




\begin{abstract}
The purpose of the cooperative research and development agreement (CRADA) between ABB Combustion Engineering, Inc. and the Oak Ridge National Laboratory (ORNL) was to develop improved, longer life, and corrosion resistance surfaces for fossil power system components for use primarily in sulfidizing environments. Four surface protection techniques were to be explored. These included diffusion process, weld overlay, hot-isostatic processing, and various spraying methods. The work was to focus on $\mathrm{Fe}_{3} \mathrm{Al}$-based iron aluminide to increase the component life. The successful completion of the CRADA would have required the achievement of the following four goals: (1) fabrication development, (2) characterization and possibly modification of the alloy to optimize its manufacturability and environmental resistance, (3) testing and evaluation of the specimens, and (4) fabrication and testing of prototype parts. Because of lack of active participation from the participant, this CRADA did not achieve all of its goals and was terminated prematurely. Work carried out at ORNL on the CRADA is described in this report.
\end{abstract}

\title{
CRADA Benefits to DOE
}

Carbon and ferritic steels of 1.25 to $9 \mathrm{Cr}$-Mo are commonly used in a range of boiler applications. Important issues for performance of these materials are related to their corrosion, sulfidation, oxidation, and erosion resistance. Iron aluminides based on $\mathrm{Fe}_{3} \mathrm{Al}$ are the potential alloys to improve all concerns with the current alloys. However, the most economical method of applying them is through the weld overlay process. This CRADA has dealt with a range of aspects related to making the weld overlays with $\mathrm{Fe}_{3} \mathrm{Al}$-based alloys and resulted in an approach of using pure aluminum as the weld wire with surface weld overlay compositions to improve corrosion and erosion resistance of steels in low $\mathrm{NO}_{\mathrm{X}}$ boilers.

\section{Technical Discussion}

\section{Alloy Identification and Basic Properties}

The $\mathrm{Fe}_{3} \mathrm{Al}$-based compositions developed at ORNL are shown in Table 1. All of these compositions contain 28 at. \% (15.9 wt \%) $\mathrm{Al}$ and 2 to 5 at. $\%$ (2 to $5 \mathrm{wt} \%) \mathrm{Cr}$. The sulfidation resistance of $\mathrm{Fe}_{3} \mathrm{Al}$-based alloys with and without chromium has been published. ${ }^{1,2}$ These data show that the $\mathrm{Fe}_{3} \mathrm{Al}$-based alloys have significantly better sulfidation resistance than type 310 stainless steel. The addition of chromium reduces the sulfidation resistance somewhat, but it is still significantly better than type 310 stainless steel.

The density and melting point data for $\mathrm{Fe}_{3} \mathrm{Al}$-based alloys are given in Table 2. These data are useful in processing and application of $\mathrm{Fe}_{3} \mathrm{Al}$-based alloys by weld overlay and other surface modification processes. The elastic modulus data for the $\mathrm{Fe}_{3} \mathrm{Al}$-based alloys are given in Table 3 . 
Table 1. Chemical composition of $\mathrm{Fe}_{3} \mathrm{Al}$-based alloys and type 310 stainless steel

\begin{tabular}{|c|c|c|c|c|}
\hline \multirow{2}{*}{ Element } & \multicolumn{4}{|c|}{ Alloy, weight percent } \\
\cline { 2 - 5 } & FAS & FAL & FA-129 & Type 310 $^{a}$ \\
\hline $\mathrm{C}$ & -- & -- & 0.05 & $0.08^{b}$ \\
\hline $\mathrm{Cr}$ & 2.2 & 5.5 & 5.5 & 25.0 \\
\hline $\mathrm{Al}$ & 15.9 & 15.9 & 15.9 & -- \\
\hline $\mathrm{B}$ & 0.012 & 0.01 & -- & -- \\
\hline $\mathrm{Zr}$ & -- & 0.15 & -- & -- \\
\hline $\mathrm{Nb}$ & -- & -- & 1.0 & -- \\
\hline $\mathrm{Mn}$ & -- & -- & -- & $2.0^{b}$ \\
\hline $\mathrm{Si}$ & -- & -- & -- & $1.50^{b}$ \\
\hline $\mathrm{Ni}$ & -- & -- & -- & 20.0 \\
\hline $\mathrm{Fe}$ & $c$ & $\mathrm{c}$ & $\mathrm{c}$ & $\mathrm{c}$ \\
\hline
\end{tabular}

${ }^{a}$ Wrought composition.

${ }^{b}$ Maximum.

'Balance.

Table 2. Density and melting point data for $\mathrm{Fe}_{3} \mathrm{Al}$-based alloys and competitive type 310 stainless steel

\begin{tabular}{|c|c|l|c|c|}
\hline \multirow{2}{*}{ Alloy } & \multicolumn{2}{|c|}{ Density } & \multicolumn{2}{c|}{ Melting temperature } \\
\cline { 2 - 5 } & lb/cu-in. & $\mathbf{g}^{\circ} \mathbf{c m}^{\mathbf{3}}$ & ${ }^{\circ} \mathbf{F}$ & ${ }^{\circ} \mathbf{C}$ \\
\hline FAS & 0.236 & 6.53 & 2606 to 2691 & 1430 to 1477 \\
\hline FAL & 0.235 & 6.51 & 2606 to 2691 & 1430 to 1477 \\
\hline FA-129 & 0.236 & 6.54 & 2606 to 2691 & 1430 to 1477 \\
\hline 310 SS & 0.290 & 8.02 & 2550 to 2650 & -- \\
\hline
\end{tabular}

Table 3. Elastic modulus of $\mathrm{Fe}_{3} \mathrm{Al}$-based alloys and 310 stainless steel

\begin{tabular}{|c|c|c|c|c|}
\hline \multirow{2}{*}{$\begin{array}{c}\text { Temperature } \\
\left({ }^{\circ} \mathbf{C}\right)\end{array}$} & \multicolumn{4}{|c|}{ Young's Modulus (GPa) } \\
\cline { 2 - 5 } & FAS & FAL & FA-129 & 310 SS \\
\hline 23 & 183.0 & 201.0 & 207.0 & 200.0 \\
\hline 150 & 178.0 & 193.0 & 198.0 & 190.0 \\
\hline 300 & 167.0 & 179.0 & $b$ & 176.0 \\
\hline 500 & 159.5 & 160.5 & 166.0 & 162.0 \\
\hline 700 & 135.0 & 148.0 & 144.0 & 141.4 \\
\hline 900 & 116.5 & 134.5 & 130.0 & 110.3 \\
\hline 1100 & 100.0 & 108.5 & 108.0 & 62.1 \\
\hline
\end{tabular}

${ }^{a}$ All data on sheet material.

${ }^{b}$ Not available. 
The thermal expansion data, which is critical for any method of surface improvement, is given in Table 4.

Table 4. Thermal expansion and thermal conductivity of wrought FA-129 alloy and 310 stainless steel

\begin{tabular}{|c|c|c|c|c|}
\hline \multirow{4}{*}{$\begin{array}{c}\text { Temp. } \\
\left({ }^{\circ} \mathbf{C}\right)\end{array}$} & $\begin{array}{c}\text { Mean coefficient } \\
\text { of expansion } \\
\left(\mathbf{1 0 - 6} /{ }^{\circ} \mathbf{C}\right)^{a}\end{array}$ & $\begin{array}{c}\text { Thermal } \\
\text { conductivity } \\
(\mathbf{w} / \mathbf{m} \cdot \mathbf{k})\end{array}$ & $\begin{array}{c}\text { Mean coefficient } \\
\text { of expansion } \\
\left(\mathbf{1 0 - 6} /{ }^{\circ} \mathbf{C}\right)^{\boldsymbol{a}}\end{array}$ & $\begin{array}{c}\text { Thermal } \\
\text { conductivity } \\
(\mathbf{w} / \mathbf{m} \cdot \mathbf{k})\end{array}$ \\
\hline 100 & 15.41 & $b$ & 14.76 & 4.76 \\
\hline 200 & 15.88 & $b$ & 15.66 & 5.66 \\
\hline 300 & 16.70 & $b$ & 16.20 & 6.06 \\
\hline 400 & 17.93 & $b$ & 16.47 & 6.64 \\
\hline 500 & 19.18 & $b$ & 16.74 & 7.51 \\
\hline 600 & 20.37 & $b$ & 16.83 & 8.37 \\
\hline 700 & 21.00 & $b$ & 18.00 & 9.53 \\
\hline 800 & 21.84 & $b$ & 18.36 & 10.05 \\
\hline 900 & 22.79 & $b$ & 18.90 & 10.80 \\
\hline 1000 & 23.38 & $b$ & 19.08 & -- \\
\hline 1100 & 23.37 & $b$ & -- & -- \\
\hline 1200 & 23.46 & $b$ & -- & - \\
\hline
\end{tabular}

${ }^{a}$ Room temperature to specified temperature.

${ }^{b}$ Not available.

The strength and ductility data of $\mathrm{Fe}_{3} \mathrm{Al}$-based alloys are shown in Fig. 1.

The $\mathrm{Fe}_{3} \mathrm{Al}$-based alloys have limited ductility in the as-cast condition at room temperature. Typical processing of cast structure occurs at $1100^{\circ} \mathrm{C}$ followed by subsequent processing at temperatures approaching 650 to $700^{\circ} \mathrm{C}$. The refinement of cast structure by processing and its heat treatment at $700^{\circ} \mathrm{C}$ followed by oil (mineral) quench yields elongation values between 10 to $18 \%$ at room temperature. The cast structure will only have an elongation of 2 to $3 \%$.

\section{Surface Enhancement of Boiler Steels with Iron Aluminide Alloy(s)}

Given the sulfidation properties, physical, and mechanical properties, the weld overlay was identified as the best method for surface enhancement of boiler steels $(1.25 \mathrm{Cr}-0.5 \mathrm{Mo}$ alloy, commonly known as T-11). The weld wire for iron aluminide was prepared by three methods. These methods are described below. 


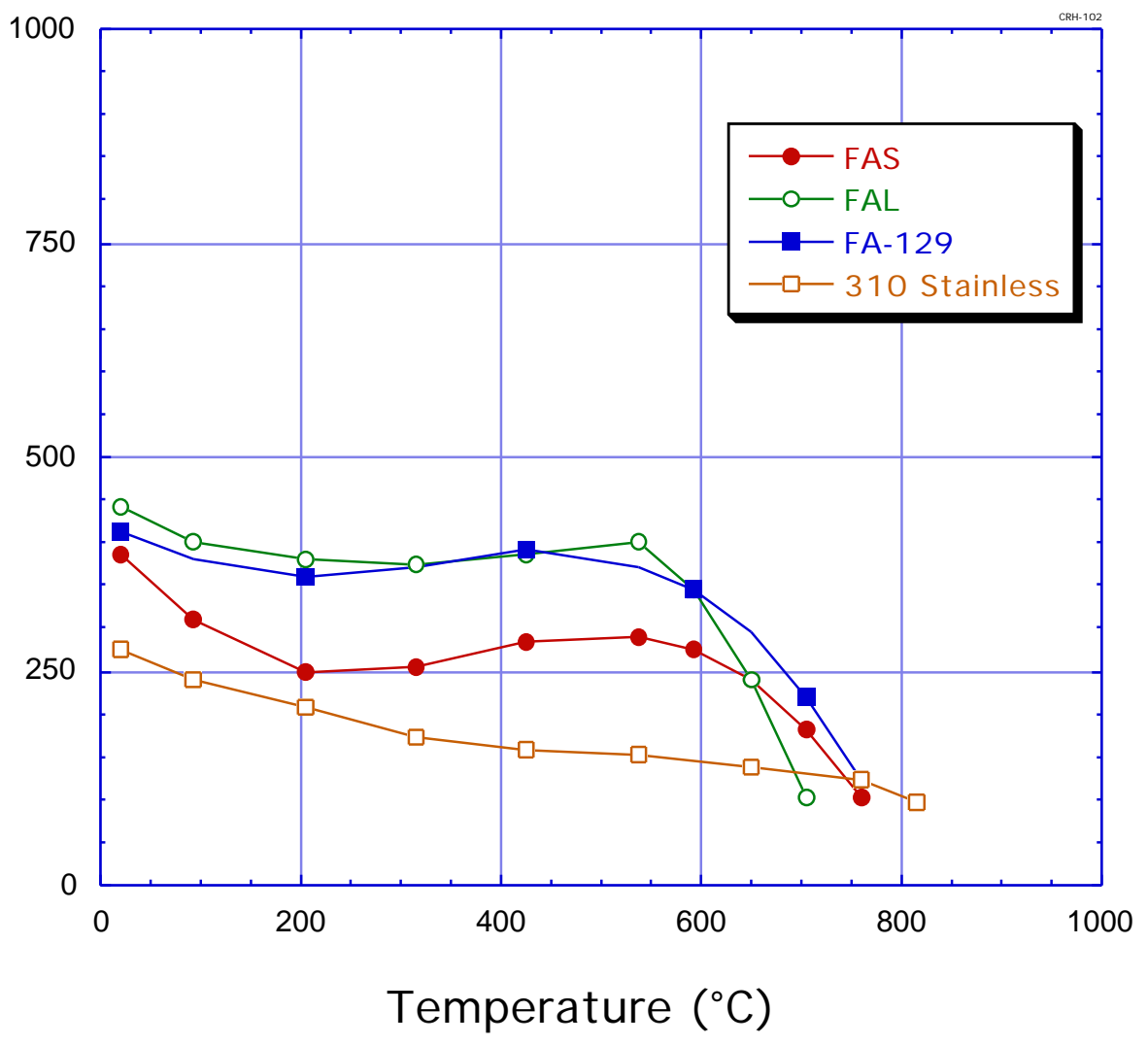

(a)

Fig. 1a. Comparison of average yield strength of wrought $\mathrm{Fe}_{3} \mathrm{Al}$-based alloys with that of 310 stainless steel. 


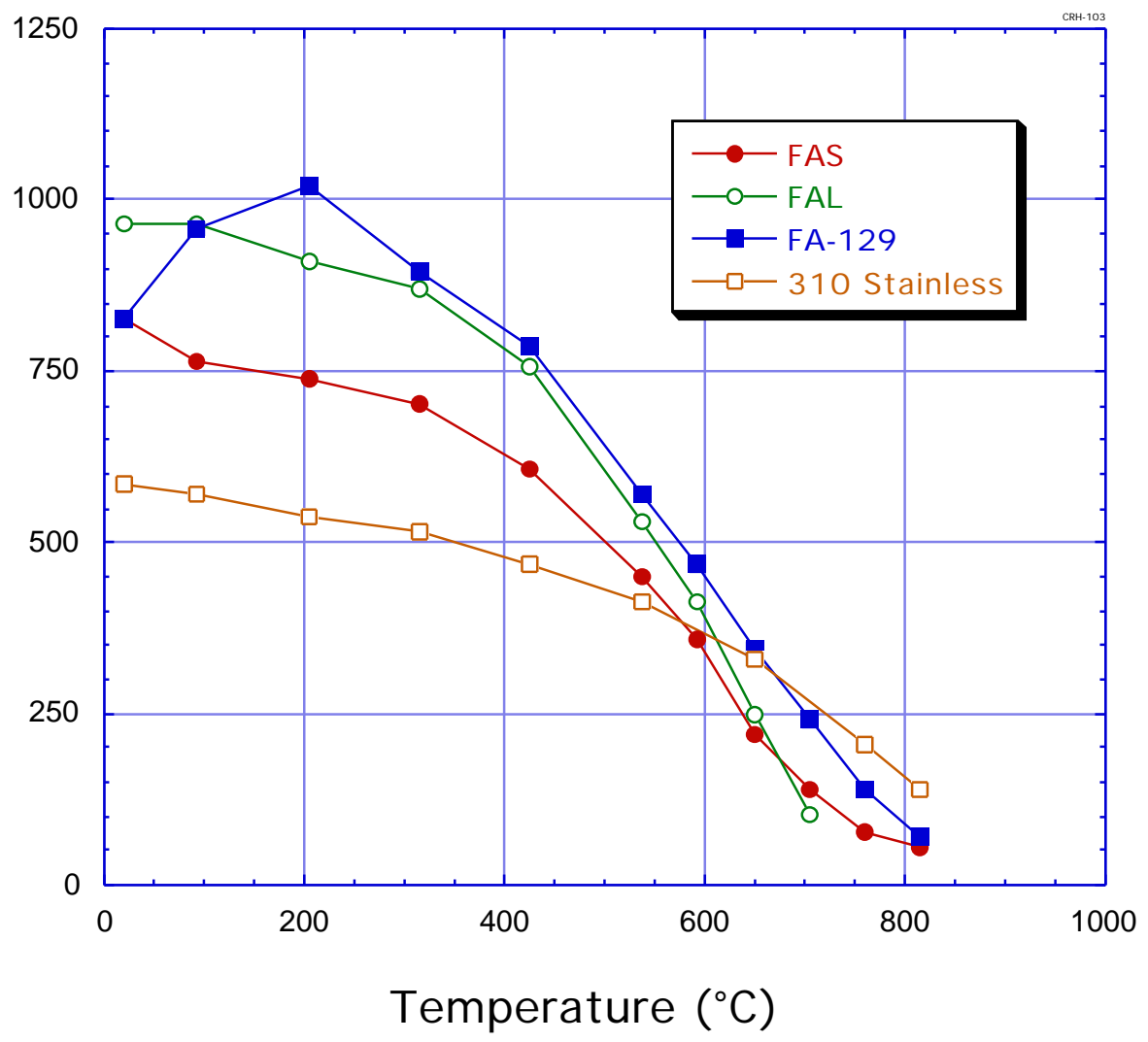

(b)

Fig. 1b. Comparison of average ultimate tensile strength of wrought $\mathrm{Fe}_{3} \mathrm{Al}$-based alloys with that of 310 stainless steel. 


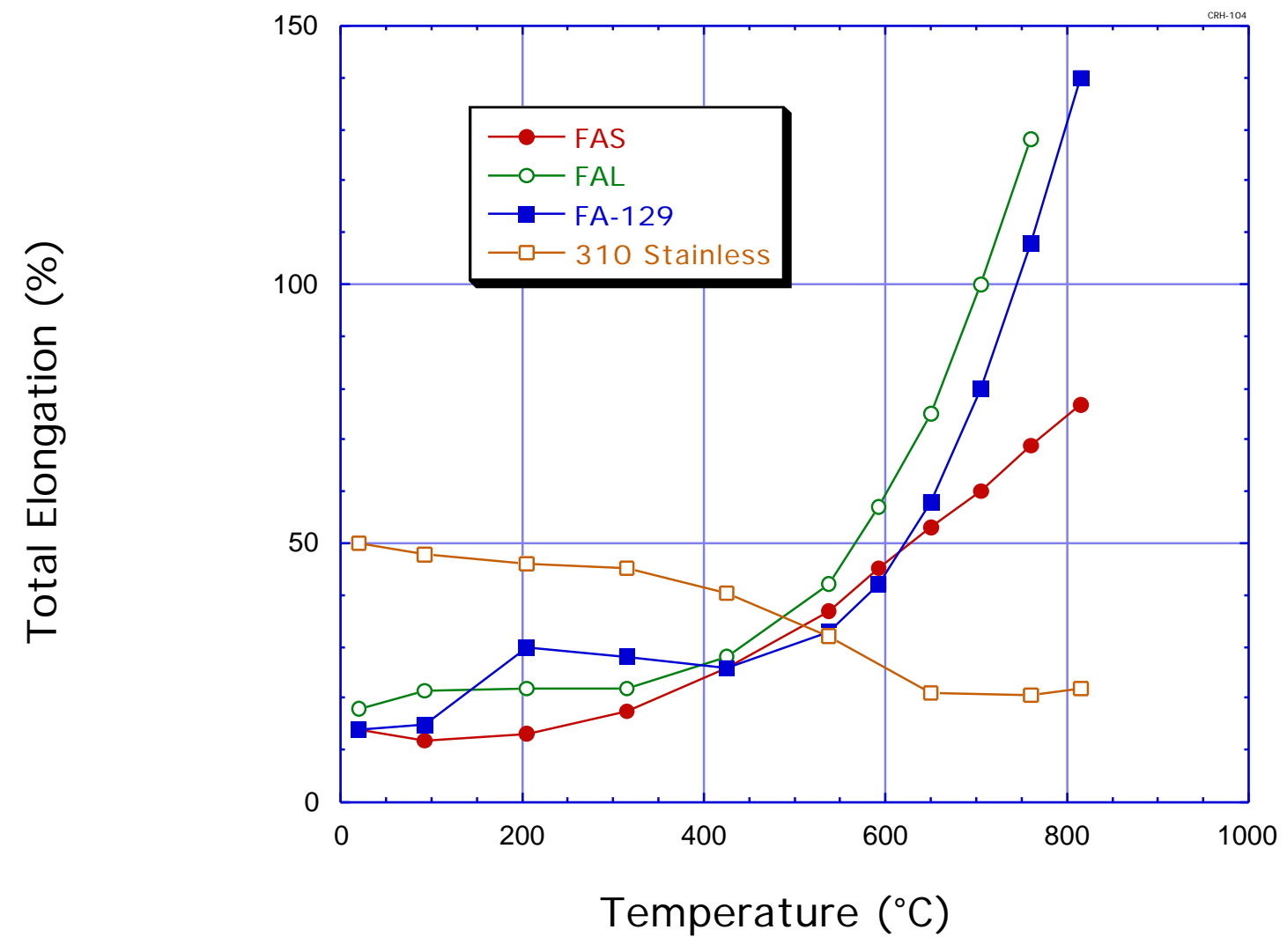

(c)

Fig. 1c. Comparison of average total elongation of wrought $\mathrm{Fe}_{3} \mathrm{Al}$-based alloys with that of 310 stainless steel. 
Short length trial wire by vacuum suction process: In this method, the desired alloy composition was air-induction melted and subsequently cast into weld wire by vacuum suction process using Pyrex ${ }^{\mathrm{TM}}$ glass tubes. The wires produced were $1 / 8$-in. diam of typical length ranging from 12 to 18 in. This method permitted an inexpensive method for processing small batches of several different compositions.

Powder cored wire with elemental powders: In this method, elemental powders of the alloy composition are filled into a carbon steel strip formed progressively into a tube. The tube is subsequently sealed and powder consolidated by wire drawing process. This process was useful for producing continuous wire of different sizes ranging from 1/16- to 1/8-in diam. Vendors such as Stoody Company can run small batches of 50 to $100 \mathrm{lbs}$ of wire by such a process. The process only requires steel strip and elemental powders. The weld process using the powder cored wire results in the desired alloy composition.

Solid core wire: In this method, a solid wire of aluminum is enclosed in a steel strip. Any of the alloying elements required is also added to the enclosure as elemental powder. This process also results in continuous wire of different sizes (1/16- to1/8-in. diam) and can be produced at a commercial vendor such as Stoody Company.

\section{Weld Overlay Process}

The weld overlay process on steels of different types (ferritic and austenitic) could be carried out using the filler wires produced by any of the methods described above. However, there were two issues noted.

1. The dilution effect in the first pass required using two weld overlay passes. The second pass generally resulted in some cracking because of low ductility in the ascast condition.

2. The desired composition could be reached by compensating the weld wire for the dilution effect. However, it was noted that the aluminum loss occurred not only from dilution but also from the evaporation process.

In order to overcome the above issues, it was decided to check if pure aluminum wire, which is commercially available, could be used for the weld overlay process. The trial welds were made using the gas-tungsten arc (GTA) welding process with direct current and argon shielding gas. During the process, a molten weld pool is first established on the base metal, to which the aluminum wire is fed. The aluminum wire melts and reacts in the pool to form an alloy in situ with the base metal. The resulting weld deposit is an alloy of aluminum and the base metal. A cross-sectional view of a weld bead deposited on plain carbon steel plate is shown in Fig. 2. The weld bead was approximately $3 \mathrm{~mm}$ thick. There was no chemical segregation in the weld region shown in Fig. 2. Also, no indication of cracking or other weld defects were observed in Fig. 2. Examination of weld beads made under identical conditions by electron microprobe analysis determined that their concentration of aluminum was about 22.4 at. \% (12.25 wt \%). For any particular overlay deposit made by GTA welding, its aluminum content will depend 


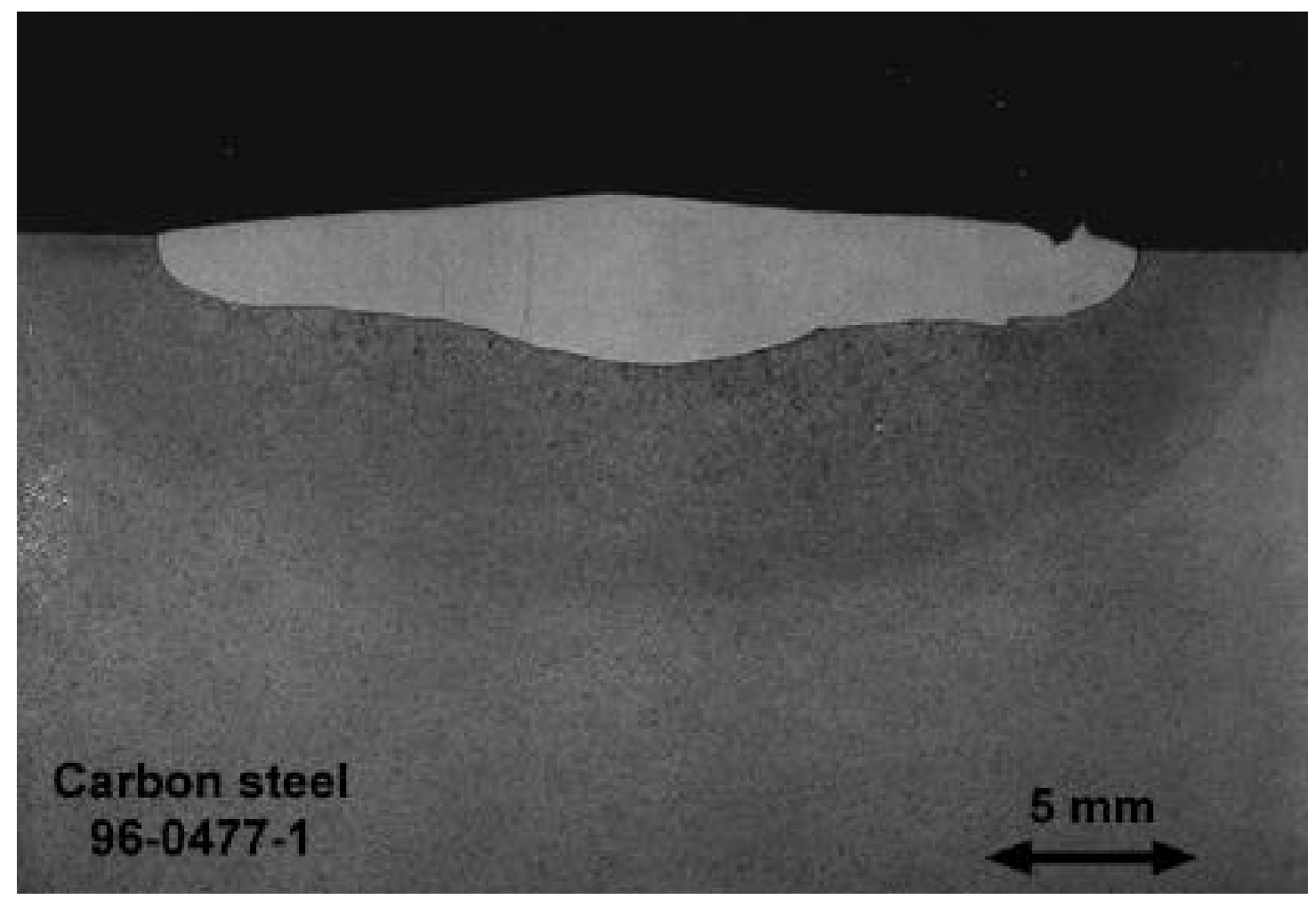

Fig. 2. Cross-sectional view of weld bead made by depositing aluminum wire on carbon steel using the gas-tungsten arc welding process.

substantially on the welding arc current, welding travel speed, and the aluminum wire feed rate into the molten weld puddle.

To further demonstrate this process, several sections of 75-mm-OD carbon steel tubing were aluminum weld overlaid by automatic GTA welding. The use of automatic welding allows for better reproducibility and uniformity of weld overlay thickness and chemical composition. A photograph of two aluminized tubing sections is shown in Fig. 3. For these welds the individual beads were deposited along the tube axes with slight overlapping. The chemical analysis results from specimens taken from several tubes are presented in Fig. 4. Each of these weld overlay deposits were made using identical welding conditions: arc current of $250 \mathrm{~A}$, voltage of $11 \mathrm{~V}$, arc travel speed of $10 \mathrm{ipm}$. However, each weld was made with a different aluminum wire feed rate, and Fig. 4 shows that as the wire feed rate increased from $10 \mathrm{in} . / \mathrm{min}$ to $18 \mathrm{in} . / \mathrm{min}$ the aluminum concentration in the weld deposit increased from 10.0 to 19.0 at. \% (5.1 to $10.2 \mathrm{wt} \%$ ). These data confirm that the aluminum concentration in the weld deposits can be controlled and varied. 


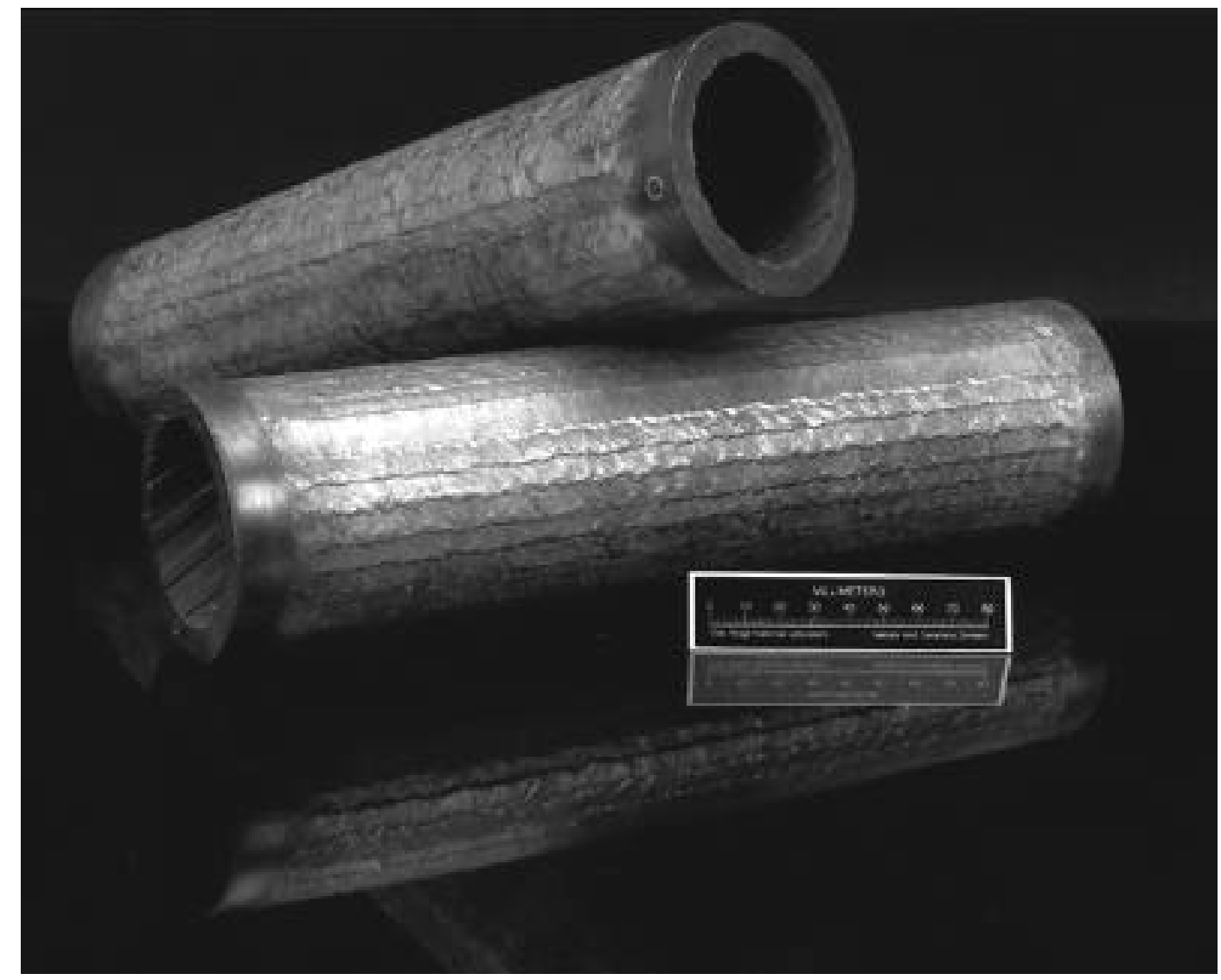

Fig. 3. Sections of 75-mm-diam carbon steel tubing that were aluminized by automatic gas-tungsten arc welding. 


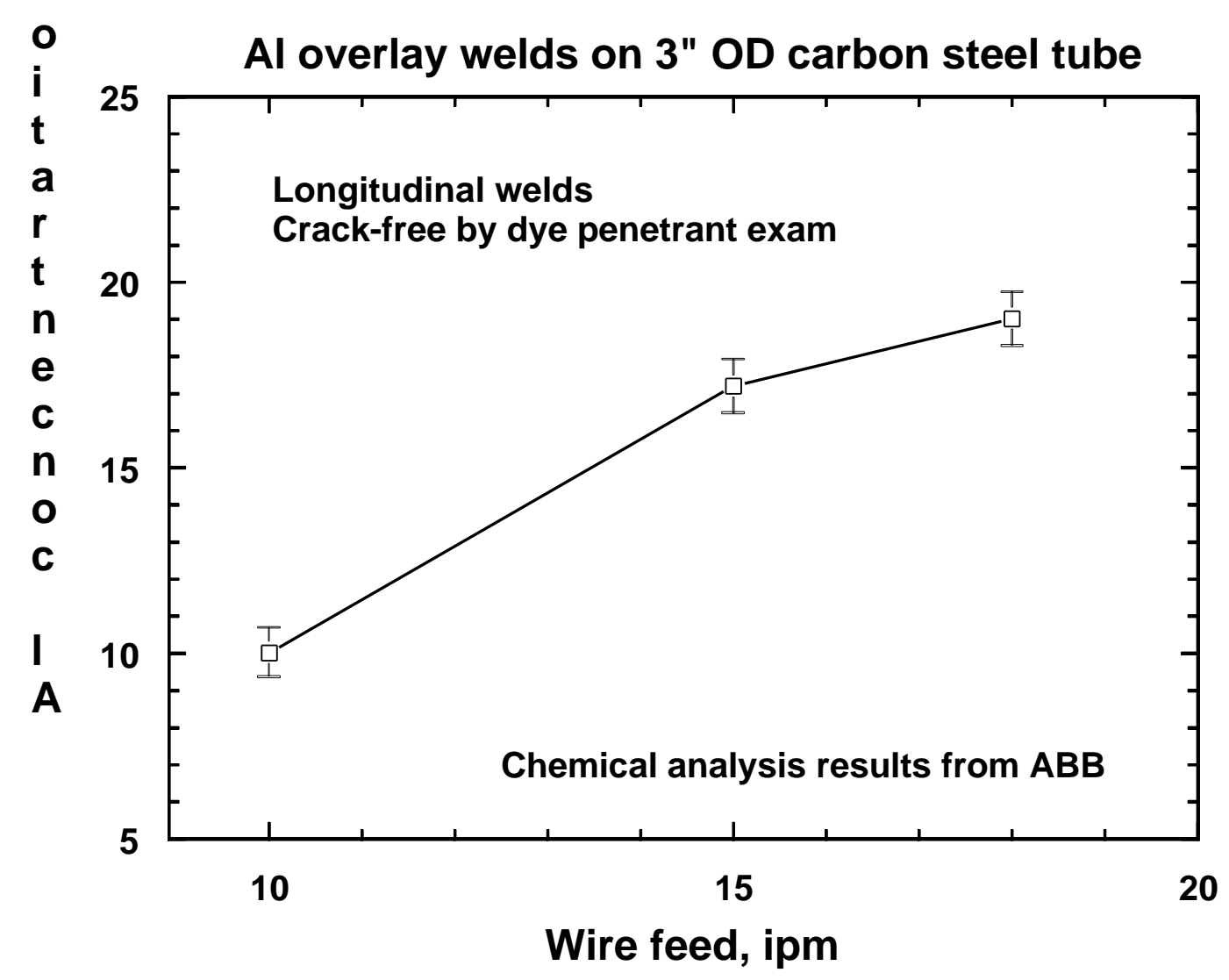

Fig. 4. Plot showing the variation of aluminum concentration in weld deposits on carbon steel with the rate of addition of aluminum wire into the weld puddle.

To assess whether the weld overlay aluminizing improved the environmental resistance of carbon steel, 0.5-in.-thick rings were cut from a tube like that shown in Fig. 3 and heated in air to temperatures of 500,750 , and $1000^{\circ} \mathrm{C}$ for $24 \mathrm{~h}$. The oxidation of the carbon steel was dramatically improved by the weld overlay. For example, at $1000^{\circ} \mathrm{C}$ the thickness of the weld overlay was unchanged in $24 \mathrm{~h}$, but the carbon steel's thickness was reduced by $0.040 \mathrm{in}$.

\section{Corrosion-Erosion Data}

An extensive corrosion-erosion study on weld overlaid composition of aluminum on steel with aluminum content of $10 \mathrm{wt} \%$ was carried out at Lehigh University. ${ }^{3}$ This study showed excellent corrosion resistance of Fe-10 wt \% weld overlays to aggressive low $\mathrm{NO}_{\mathrm{X}}$ gas compositions and comparable erosion rates to commercially used alloys in the service temperature range (below $600^{\circ} \mathrm{C}$ ). The study further concluded that with the requirement of combination of weldability and corrosion resistance in moderately 
reducing environments, weld overlaid steels with aluminum are viable candidates for further evaluation for use as sulfidation-resistant weld overlays.

\section{Inventions}

The aluminum weld overlay process was invented (patent pending) through a separate work under way on weld overlay of $\mathrm{FeAl}$ (not $\mathrm{Fe}_{3} \mathrm{Al}$ ) compositions on steel. However, since resulting aluminum levels were of interest to the CRADA, some work was carried out on boiler tubes to demonstrate the applicability of the process.

\section{Commercialization Possibilities}

As additional corrosion and erosion data become available on steels weld overlaid with aluminum, there is strong potential for their commercial applications for boilers.

\section{Plans for Future Collaboration}

There are no plans for future collaboration in this area with ABB (now Alstom Power).

\section{Conclusions}

There was minimal interaction from $\mathrm{ABB}$ on this CRADA with ORNL. However, still it resulted in the evaluation of $\mathrm{Fe}_{3} \mathrm{Al}$-based iron aluminides as weld overlays of steels for improved corrosion and erosion resistance. Results of this CRADA demonstrated that while it was difficult to implement the weld overlays of $\mathrm{Fe}_{3} \mathrm{Al}$-based compositions, good results in producing corrosion- and erosion-resistant surfaces could be obtained through the use of weld overlays with pure aluminum wire. Testing of such coating at Lehigh University has confirmed the good combination of corrosion and erosion performance for low $\mathrm{NO}_{\mathrm{X}}$ boiler environments.

\section{Acknowledgments}

The authors would like to thank C. R. Howell for plotting and M. L. Atchley for preparing the manuscript.

This research was supported through a CRADA with ABB Combustion Engineering Inc., sponsored by the U.S. Department of Energy, Office of Fossil Energy, Advanced Research Materials Program under Contract DE-AC05-00OR22725 with Oak Ridge National Laboratory and managed by UT-Battelle, LLC. 


\section{References}

12. C. G. McKamey, J. H. DeVan, P. F. Tortorelli, and V. K. Sikka, J. Mater. Res., 6(8), (1991) 1779-1805.

13. K. Natesan and P. F. Tortorelli, "High-Temperature Corrosion and Applications of Nickel and Iron Aluminides in Coal-Conversion Power Systems," p. 265 in International Symposium on Nickel and Iron Aluminides: Processing, Properties, and Applications, ed. S. C. Deevi, V. K. Sikka, P. J. Maziasz, and R. W. Cahn, ASM International, Materials Park, OH, 1997.

14. S. W. Banovic, J. N. DuPont, B. F. Levin, and A. R. Marder, "Investigation of Iron Aluminide Weld Overlays - Final Report," ORNL/Sub/95-SU604/02, Lehigh University, Bethlehem, PA, 1999. 
C/ORNL92-0143

\section{INTERNAL DISTRIBUTION}

1. E. E. Bloom

2. S. A. David

3. R. R. Judkins

4. C. G. McKamey

5. T. M. Rosseel

6. M. L. Santella

7. V. K. Sikka

8. R. W. Swindeman

9. P. F. Tortorelli

10. P. J. Wenzel

11. K. M. Wilson

12. I. G. Wright

13. Office of Technical Information and Classification, 4500N, 6254

\section{EXTERNAL DISTRIBUTION}

14-15. ABB CE Power Products Mfg., 911 W. Main Street, Chattanooga, TN 37402

D. A. Canonico

J. F. Henry

16. DOE, FE-25, Office of Advanced Research, 19901 Germantown Rd., Germantown, MD 20874

F. M. Glaser

17. DOE/ORO, 4500N, 6269

P. A. Carpenter

18. DOE-WFO, MS G209 